\title{
HISTOPATHOLOGY AND MOLECULAR CHARACTERIZATION OF MICROSPORIDIAN PARASITES IN CULTURED SHRIMP PENAEUS MONODON FABRICIUS 1798 OF BANGLADESH
}

\author{
MD. MUNJUR HOSSAIN ${ }^{1}$, NUSRAT JAHAN PUNOM ${ }^{1}$, MD. MOSTAVI ENAN ESHIK ${ }^{1}$, \\ MST KHADIZA BEGUM ${ }^{1}$, MD. AMINUL ISLAM BHUIYAN ${ }^{2}$ \\ AND MOHAMMAD SHAMSUR RAHMAN ${ }^{1 *}$ \\ ${ }^{1}$ Department of Fisheries, University of Dhaka, Dhaka 1000, Bangladesh. \\ ${ }^{2}$ Department of Zoology, University of Dhaka, Dhaka 1000, Bangladesh.
}

\begin{abstract}
Black tiger shrimp (Penaeus monodon Fabricius 1798) cultured in Bangladesh was investigated for the presence of microsporidian parasite. Histological section of hepatopancreas showed a large number of microsporidian spores under light microscopy. Spores under scanning electron microscope appeared oval shapes. Histology of infected shrimps showed severe degeneration of hepatopancreatic tubules. Early and late stage of microsporidian parasites in hepatopancreatic tubules were also observed. DNA extracted from the hepatopancreas of shrimps were subjected to PCR amplification using primers targeting microsporidian SSU rRNA gene. The PCR amplified an expected product of $\sim 328 \mathrm{bp}$ and the sequences showed $81-82 \%$ identity with the Paranucleospora theridion reported from western Norway in 2008. Further screening of field samples was carried out using EHP-specific primers. DNA extracted from ten hepatopancreas samples of $P$. monodon were tested and none found to be positive for EHP (Enterocytozoon hepatopenaei). This is the first report for the identification of microsporidian parasites in cultured shrimp along the south-west region of Bangladesh.
\end{abstract}

Key words: Microsporidia, Shrimp disease, Molecular characterization

\section{Introduction}

The giant tiger prawn or Asian black tiger shrimp, Penaeus monodon (Fabricius 1798), is widely cultivated as a delicious food item. This sector represents the second largest export industry for Bangladesh after garments where 97\% of the shrimp produced being exported (Kruijssen et al. 2012). Nowadays, the shrimp industry is under threat due to various disease attacks such as bacterial, viral and parasitic diseases, especially microsporidian parasites causing reduced growth, thereby decrease the total production. Microsporidian parasites are dangerous form of pathogen found around the world. These spore-forming unicellular parasites can affect aquaculture severely. Shrimp farms in Asia have been reporting heavy infection with a microsporidian parasite, Enterocytozoon hepatopenaei (EHP) in cultured P. vannamei affecting the production due to severe growth retardation (Newman 2015). The parasite was first recorded from growth retarded tiger shrimp, P. monodon from Thailand (Chayaburakul

\footnotetext{
*Author for correspondence: <shamsur@du.ac.bd>
} 
et al. 2004) and subsequently, the parasite was identified and characterised from $P$. monodon in Thailand in 2009 (Tourtip et al. 2009). White opacity or milky discoloration associated with the musculature are the characteristics of diseased shrimp. In English, these microsporidian-infected shrimp are known as 'cotton shrimp' or 'milk shrimp' (Bell and Lightner 1988). In western Norway, microsporidian parasite, Paranucleospora theridion was first isolated in farmed Atlantic salmon which suffered from gill disease (Nylund et al. 2010). Besides Atlantic salmon, this parasite was detected in Salmo trutta, Oncorhynchus mykiss, Lepeophtheirus salmonis and Caligus elongates (Nylund et al. 2011). The detection of microsporidian parasite in cultured shrimp has not been done yet in Bangladesh. So, the present study was undertaken to focus mostly on detection and molecular characterization of the microsporidian parasite in cultured shrimp collected from different regions of southwest Bangladesh, especially from Satkhira and Bagerhat districts.

\section{Materials and Methods}

Shrimp sample collection: From Satkhira Sadar Upazila, 22 shrimp samples of 3 - 4 months old were collected, and eight samples were collected from Bagerhat district (four from Morrelganj and four from Mongla upazila). Total 30 shrimp samples were collected from different farms of Satkhira and Bagerhat districts during April 2016 to November 2016. These farms were experiencing size variation or growth retardation in shrimp.

Histopathology: For histopathological observation 20 samples of hepatopancreas were dissected out and kept in the fixative (Bouin's fluid) for $18 \mathrm{hrs}$ and processed using routine histological techniques (Bell and Lightner 1988) in the Parasitology Laboratory, Department of Zoology, University of Dhaka. Briefly, the tissues were dehydrated in graded alcohol series (70, 90 and 100\%) for 45, 5- 10 and 5 - 15 mins. After dehydration, tissues were treated with xylene for 10-15 mins, then samples were transferred into xylene with the wax solution for proper saturation and paraffin blocks were prepared through tissue embedding system. Tissue sections (4 - $5 \mu \mathrm{m})$ were taken to further process and stained with hematoxylin and counter-stained with eosin using the standard procedure. The stained tissue sections were made permanent for microscopic study.

Scanning electronic microscopy (SEM): The facilities for SEM were availed in Centre for Advanced Research in Sciences (CARS), University of Dhaka. For SEM, small sections of hepatopancreas were fixed in Bouin's fluid. Washing and dehydration in an ascending series of ethanol solutions, critical point dried with $\mathrm{CO}_{2}$ and coated with platinum were followed for the scanning electronic microscopy (JEOL JSM-6490LA, Germany). 
DNA extraction: Total DNA was extracted from the hepatopancreas using a commercial tissue extraction kit (Qiagen, Germany). The absorbance of purified DNA was checked by Nano Drop 2000 UV-Vis spectrophotometer (Thermo Fisher Scentific Inc., USA) at INVENT Technologies Ltd., Dhaka.

PCR amplification and sequencing: For the amplification of the small subunit ribosomal RNA (SSU rRNA) gene fragment, PCR amplification was performed using primers targeting microsporidian SSU rRNA gene (MF1-5'CAGCAGCCGCGGTAA TTCC-3' and MR1-5 'CCCGTGTTGAGT CAAATTAAGC-3`) as reported by Hadziavdic et al. (2014). The PCR amplification followed 32 cycles of denaturation at $95^{\circ} \mathrm{C}$ for $30 \mathrm{sec}$, annealing at $53^{\circ} \mathrm{C}$ for $30 \mathrm{sec}$, and extension at $72^{\circ} \mathrm{C}$ for $1 \mathrm{~min}$, followed by $5 \mathrm{~min}$ final extension at $72^{\circ} \mathrm{C}$.

For the detection of Enterocytozoon hepatopenaei (EHP) infection in shrimp, PCR was performed with one set of EHP-510 specific primer. The primers for detecting the EHP were EHP-510F (5'-GCCTGAGAGATGGCTCCCACGT) and EHP-510R (5'GCGTA CTATCCCCAGAGCCCGA) (Tang et al. 2015). Amplifications were performed with the following cycling parameters: initial denaturation at $94^{\circ} \mathrm{C}$ for 3 min, followed by 35 cycles of $94^{\circ} \mathrm{C}$ for $30 \mathrm{sec}, 60^{\circ} \mathrm{C}$ for $30 \mathrm{sec}$, and $72^{\circ} \mathrm{C}$ for $30 \mathrm{sec}$, and a final extension at $72^{\circ} \mathrm{C}$ for $5 \mathrm{~min}$.

The successful amplification of the desired genes was visualized in $1 \%$ agarose gel with ethidium bromide depending on the size of amplicon. DNA bands were observed and visualized by Alpha Imager MINI gel-documentation system. The amplified PCR specific products were purified with the PCR Clean-up System Kit (Promega, USA) according to the manufacturer's instruction prior to sequencing and the products were commercially sequenced at First Base Laboratories, Malaysia (http://www.firstbaselab. com/). Sequence analysis was done using BLASTn and CLUSTALW.

Phylogenetic analysis: SSU rRNA sequences of studied microsporidian isolates under study, including downloaded sequences from NCBI GenBank, were selected for phylogenetic analysis. A maximum-likelihood (ML) analysis with neighbor-joining method was conducted through MEGA version 7 (Kumar et al. 2016). Bootstrap analyses (1000 times) for ML were performed to evaluate the robustness of the phylogenies.

\section{Results and Discussion}

Histopathology: About 3 - 4 months cultured sub-adults and adults Penaeus monodon were randomly collected from farms (Fig. 1). This study confirmed the presence of microsporidian spores (Fig. 2) only in the cytoplasm of epithelial cells of hepatopancreas. 


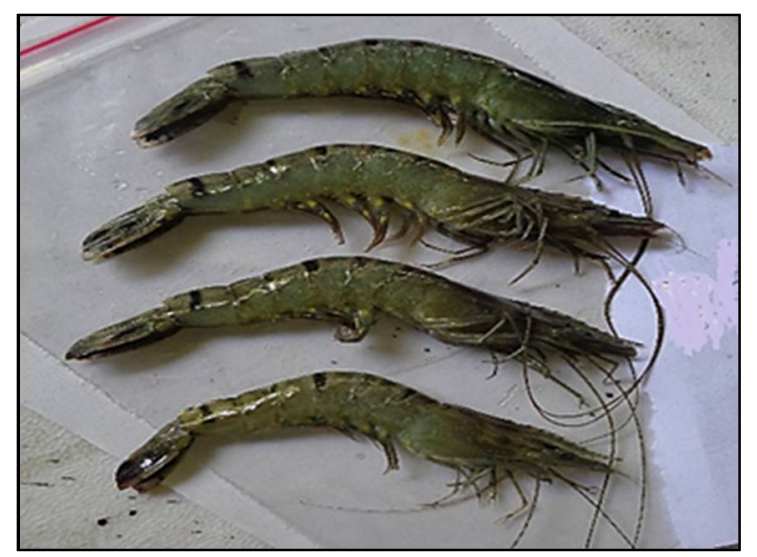

Fig. 1. Farm-level observations made during the collection of samples of P. monodon.

Table 1. Overview of results for the identification of the microsporidian parasite in cultured shrimp samples collected from south-west farming region of Bangladesh.

\begin{tabular}{|c|c|c|c|c|c|c|c|c|}
\hline \multirow{2}{*}{$\begin{array}{l}\text { Sl. } \\
\text { No. }\end{array}$} & \multirow{2}{*}{$\begin{array}{l}\text { Sample } \\
\text { No. }\end{array}$} & \multirow{2}{*}{$\begin{array}{l}\text { Sampling } \\
\text { area }\end{array}$} & \multirow{2}{*}{$\begin{array}{l}\text { Area of } \\
\text { the farm } \\
\text { (ha) }\end{array}$} & \multirow{2}{*}{$\begin{array}{c}\text { Infected } \\
\text { representative } \\
\text { organ sample }\end{array}$} & \multicolumn{2}{|c|}{ Histology } & \multicolumn{2}{|c|}{ Molecular diagnosis } \\
\hline & & & & & $\begin{array}{c}\text { Light } \\
\text { microscopy }\end{array}$ & SEM & $\begin{array}{r}\text { SSU } \\
\text { rRNA }\end{array}$ & EHP-510 \\
\hline 1 & 3 & $\begin{array}{l}\text { Satkhira } \\
\text { sadar }\end{array}$ & 1.12 & $\begin{array}{l}\text { Hepato- } \\
\text { pancreas }\end{array}$ & $\sqrt{ }(+)$ & $\sqrt{ }(+)$ & $\sqrt{ }(+)$ & $\sqrt{ }(-)$ \\
\hline 2 & 6 & " & 0.48 & " & $\sqrt{ }(+)$ & $\sim$ & $\sim$ & $\sim$ \\
\hline 3 & 9 & $"$ & 1.61 & $"$ & $\sqrt{ }(+)$ & $\sqrt{ }(+)$ & NA & $\sqrt{ }(-)$ \\
\hline 4 & 12 & $"$ & 0.64 & $"$ & $\sqrt{ }(+)$ & $\sim$ & $\sim$ & $\sim$ \\
\hline 5 & 15 & $"$ & 0.80 & $"$ & $\sqrt{ }(+)$ & $\sim$ & NA & $\sqrt{ }(-)$ \\
\hline 6 & 19 & $"$ & 0.96 & $"$ & $\sqrt{ }(+)$ & $\sim$ & $\sim$ & $\sim$ \\
\hline 7 & 20 & $"$ & 2.89 & $"$ & $\sqrt{ }(+)$ & $\sqrt{ }(+)$ & $\sqrt{ }(+)$ & $\sqrt{ }(-)$ \\
\hline 8 & 21 & $"$ & 3.21 & $"$ & $\sqrt{ }(+)$ & $\sim$ & $\sim$ & $\sim$ \\
\hline 9 & 32 & $"$ & 0.80 & $"$ & $\sqrt{ }(+)$ & $\sim$ & NA & $\sqrt{ }(-)$ \\
\hline 10 & 33 & $"$ & 0.64 & $"$ & $\sqrt{ }(-)$ & $\sim$ & $\sim$ & $\sim$ \\
\hline 11 & 37 & $"$ & 0.64 & $"$ & $\sqrt{ }(+)$ & $\sqrt{ }(+)$ & NA & $\sqrt{ }(-)$ \\
\hline 12 & 39 & " & 8.03 & $"$ & $\sqrt{ }(+)$ & $\sim$ & NA & $\sqrt{ }(-)$ \\
\hline 13 & 27 & $\begin{array}{l}\text { Mongla, } \\
\text { Bagerhat }\end{array}$ & 1.12 & $"$ & $\sqrt{ }(-)$ & $\sim$ & $\sim$ & $\sim$ \\
\hline 14 & 28 & " & 0.96 & $"$ & $\sqrt{ }(+)$ & $\sqrt{ }(+)$ & $\sqrt{ }(-)$ & $\sqrt{ }(-)$ \\
\hline 15 & 29 & $"$ & 1.45 & $"$ & $\sqrt{ }(+)$ & $\sim$ & $\sim$ & $\sim$ \\
\hline 16 & 30 & " & 0.80 & $"$ & $\sqrt{ }(-)$ & $\sim$ & $\sim$ & $\sim$ \\
\hline 17 & 23 & $\begin{array}{l}\text { Morrelganj, } \\
\text { Bagerhat }\end{array}$ & 0.96 & $"$ & $\sqrt{ }(+)$ & $\sqrt{ }(+)$ & $\sqrt{ }(-)$ & $\sqrt{ }(-)$ \\
\hline 18 & 24 & " & 1.93 & $"$ & $\sqrt{ }(-)$ & $\sim$ & $\sim$ & $\sim$ \\
\hline 19 & 25 & $"$ & 1.61 & $"$ & $\sqrt{ }(-)$ & $\sim$ & $\sim$ & $\sim$ \\
\hline 20 & 26 & $"$ & 2.41 & $"$ & $\sqrt{ }(+)$ & $\sim$ & $\sqrt{ }(-)$ & $\sqrt{ }(-)$ \\
\hline
\end{tabular}

$[\sqrt{ }(+)=$ Analysis was performed and showed positive result, $\sqrt{ }(-)=$ Analysis was performed and showed negative result, $\sim$ denotes analysis was not performed and $\mathrm{NA}=$ Not-amplified]. 
Out of 20 hepatopancreatic samples, 15 showed positive results for the prevalence of microsporidian spores. This result also confirmed about serious necrotic changes in hepatopancreas where elliptical and ovoid shaped eosinophilic to basophilic formations indicating presumptive developmental stages of the microsporidian in the tubular epithelium.

These stages were transcendently found in the distal ends of hepatopancreatic tubules and the greater part of the tubular epithelium in this area demonstrated separation from the basal membrane. In the basal part of the tubular epithelium, granular material and spore-like structures were seen.
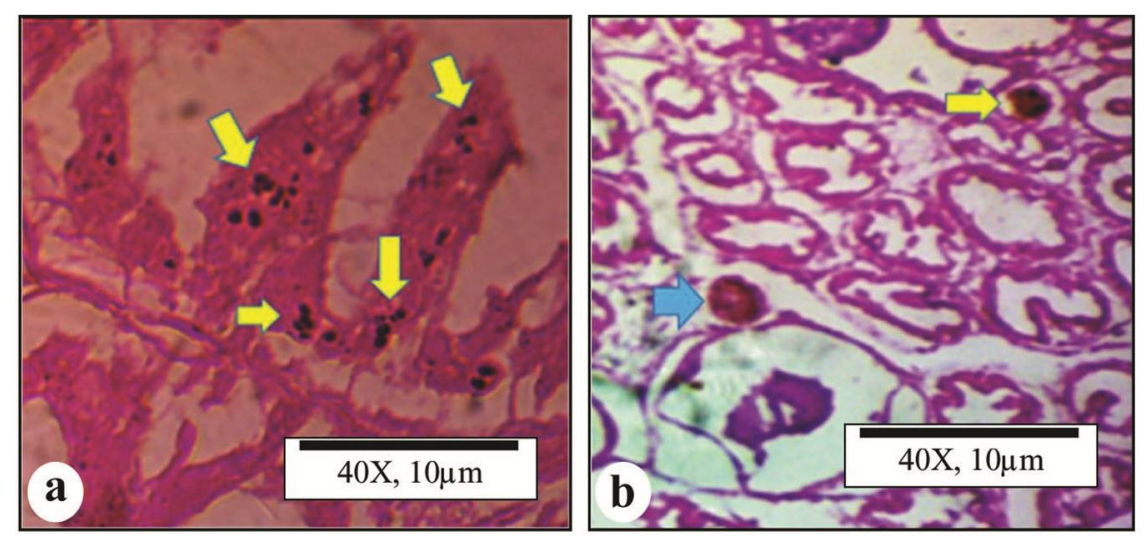

Fig. 2a,b. Haematoxylin-eosin (H\&E)-stained section of hepatopancreatic tissue. (a) Yellow color arrow indicated the microsporidian parasite. (b) Light blue color arrow represented the late plasmodium stage of microsporidian parasite.

Histological study confirmed the severe necrotic changes in the hepatopancreas. Toubiana et al. (2004) observed the morphology of the microsporidian spores in penaeid shrimp along the west coast of Madagascar. They confirmed the spore size $(2.6 \times 1.6 \mu \mathrm{m})$ and morphology (ovoid) for the parasites tainting $F$. indicus and $P$. semisulcatus both were not significantly different, recommending that they may be a similar microsporidian species.

Scanning electronic microscopy (SEM): After observation in SEM, spores showed irregular in size and dimorphic with large and small size. Samples were examined with magnifications up to 700, 1000, 5000 and 25000 and with the diameter of 1, 5, 10 and $20 \mu \mathrm{m}$. All the six samples showed the positive result for microsporidian parasite (Fig. 3 ). The localization of plasmodium and morphology of the spores observed in the present study were similar to the microsporidian parasite $P$. theridion. 

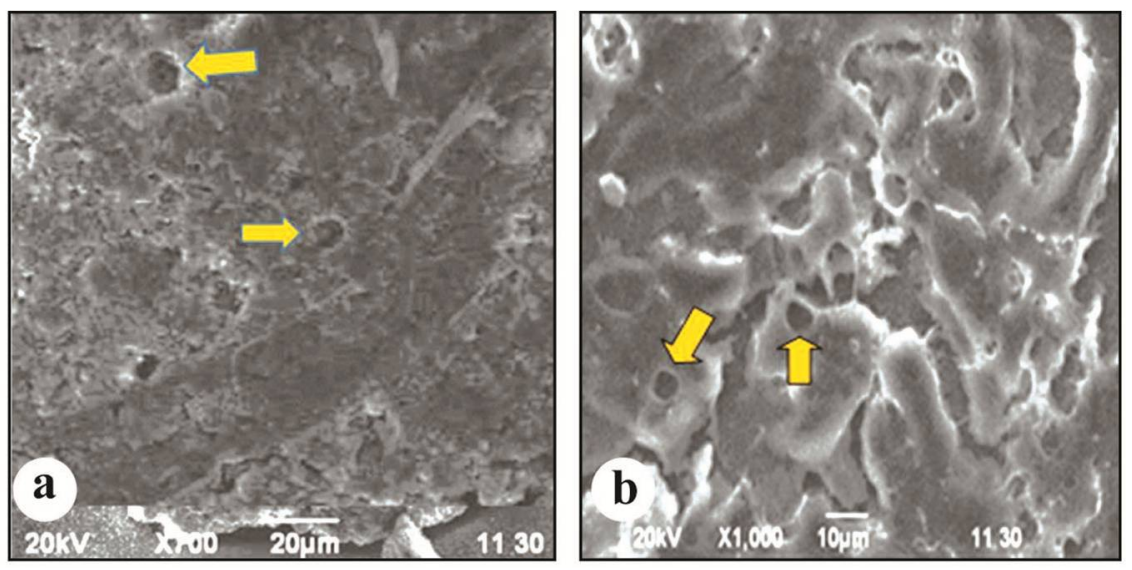

Fig. 3. Scanning electron microscopic observation of spores of microsporidian parasite in hepatopancreatic tissue of $P$. monodon at 700 (a) and 1000 (b) magnification.

Molecular identification of microsporidian parasite: The PCR amplification produced a product size of $500-650 \mathrm{bp}$. Out of ten samples, five confirmed positive bands for 18S rRNA primer (Fig. 4). These five positive PCR products were sequenced and all DNA sequence was obtained up to $540 \mathrm{nt}$.

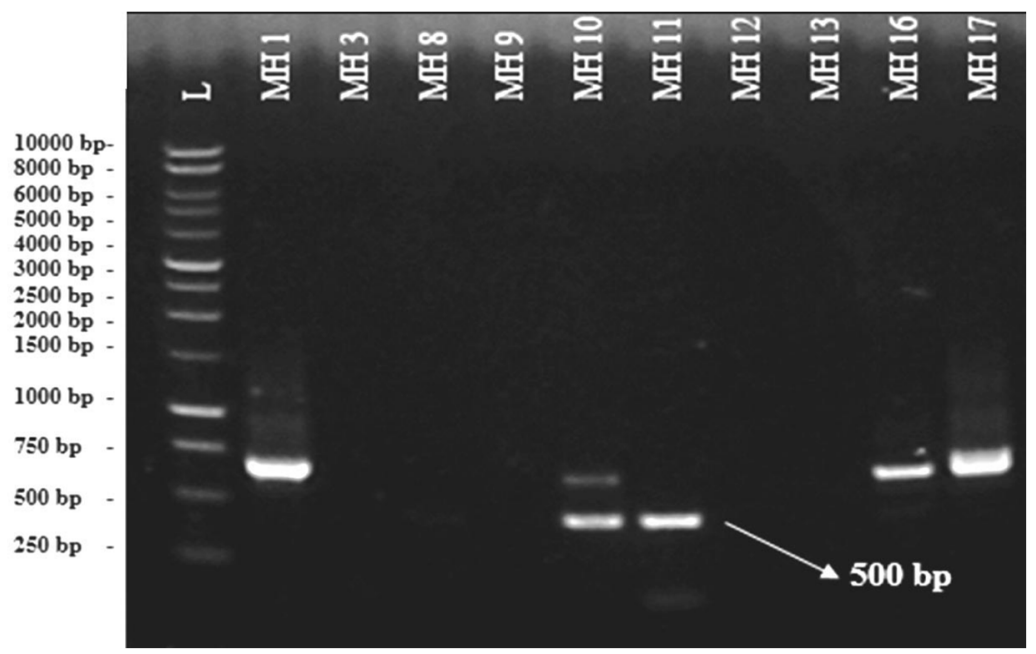

Fig. 4. Agarose gel (1\%) electrophoresis of SSU rRNA primer generated PCR products for 10 different samples and $\mathrm{L}$ denotes DNA ladder of $1 \mathrm{~kb}$ marker.

SSU rRNA sequence based identification: After analyzing the sequences generated by primers specific to $18 \mathrm{~S}$ rRNA for its quality, the primer sequences were discarded and the remaining $328 \mathrm{nt}$ sequences was subjected to BLASTn search.The search revealed 
100 hits in the database and from five representative sequences, two sequences (MH10 and MH11) were finally found to be related to microsporidian records showing $81 \sim 82 \%$ identity with the $P$. theridion (GenBank accession no. FJ594971) (Table 2).

Nucleotide sequence accession numbers: The reported sequences in this study have beensubmitted to the NCBI GenBank database under accession numbers MH428217MH428218.

Table 2. SSU rRNA sequence ( $328 \mathrm{bp}$ ) based identification of four representative samples.

\begin{tabular}{|c|c|c|c|c|c|c|c|}
\hline $\begin{array}{l}\text { Sample } \\
\text { No. }\end{array}$ & $\begin{array}{l}\text { Strain Identified species } \\
\text { ID }\end{array}$ & $\begin{array}{l}\text { Total } \\
\text { score }\end{array}$ & $\begin{array}{l}\text { Query } \\
\text { cover }\end{array}$ & $\begin{array}{c}E \\
\text { value }\end{array}$ & Identity & $\begin{array}{l}\text { GenBank } \\
\text { Acc. no. }\end{array}$ & $\begin{array}{l}\text { GenBank Acc. of } \\
\text { studied sample }\end{array}$ \\
\hline 3 & $\begin{array}{l}\text { MH10 Paranucleospora } \\
\text { theridion isolate } \\
\text { RB040612-11Pt small } \\
\text { subunit rRNA gene }\end{array}$ & 276 & $98 \%$ & $3 e-70$ & $82 \%$ & KR187185 & MH428217 \\
\hline 20 & $\begin{array}{l}\text { MH11 Paranucleospora } \\
\text { theridion isolate } \\
\text { RB040612-11Pt small } \\
\text { subunit rRNA gene }\end{array}$ & 274 & $100 \%$ & $1 e-69$ & $81 \%$ & KR187185 & MH428218 \\
\hline
\end{tabular}

Pair-wise sequence alignment: The comparison of sequences of the two microsporidian strains MH10 and MH11 with the downloaded sequences showed 58 polymorphic sites among them. The pairwise alignment were performed between MH10 and MH11, where only one polymorphic site was observed among them. Therefore, pairwise sequence comparison of the novel microsporidium with MH10 and MH11 revealed 99.7\% sequence identities (Fig. 5).

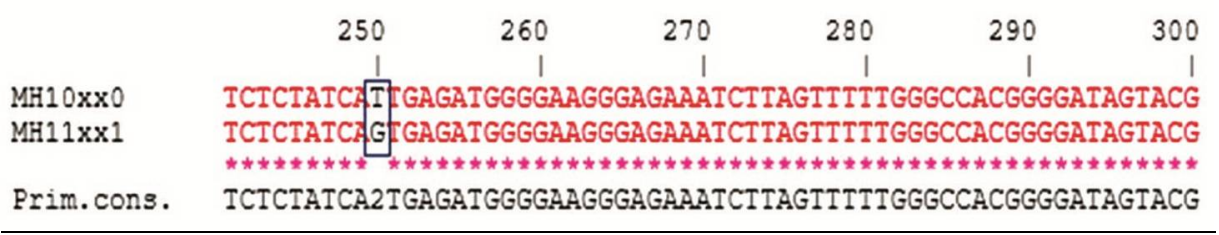

Fig. 5. Pairwise sequence alignment of SSU rRNA gene fragments of the MH10 and MH11 where black among the red indicates polymorphic sites.

Phylogeny test: Desmozoon lepeophtherii (HM800847.2), Paranucleospora theridion (FJ594976.1), P. theridion (FJ594971.1), D. lepeophtherii (AJ431366.2), P. theridion (FJ594988.1) were used as a reference sequences to test the phylogeny of identified microsporidian strains (Fig. 6).

Microsporidian parasites have been reporting in penaeid shrimp of numerous biogeographic regions. From farms of Thailand, Agmasoma penaei appear to be a parasite of Penaeus monodon and Fenneropenaeus merguiensis (also known as $P$. merguiensis) (Flegel et al. 1992). The genus Thelohania of microsporidians is parasites 
of F. merguiensis in tropical Australia (Owens and Hall-Mendelin 1990) and Pandalus jordani in the United States (Olson and Lannan 1984). In 2008, the microsporidian parasite Paranucleospora theridion was also discovered in Atlantic salmon Salmosalar suffering from proliferative gill disease in a marine farm of western Norway (Nylund et al. 2011). The results of this study denoted that microsporidian parasite is present in the south-west region of Bangladesh especially in Satkhira and Bagherhat districts.

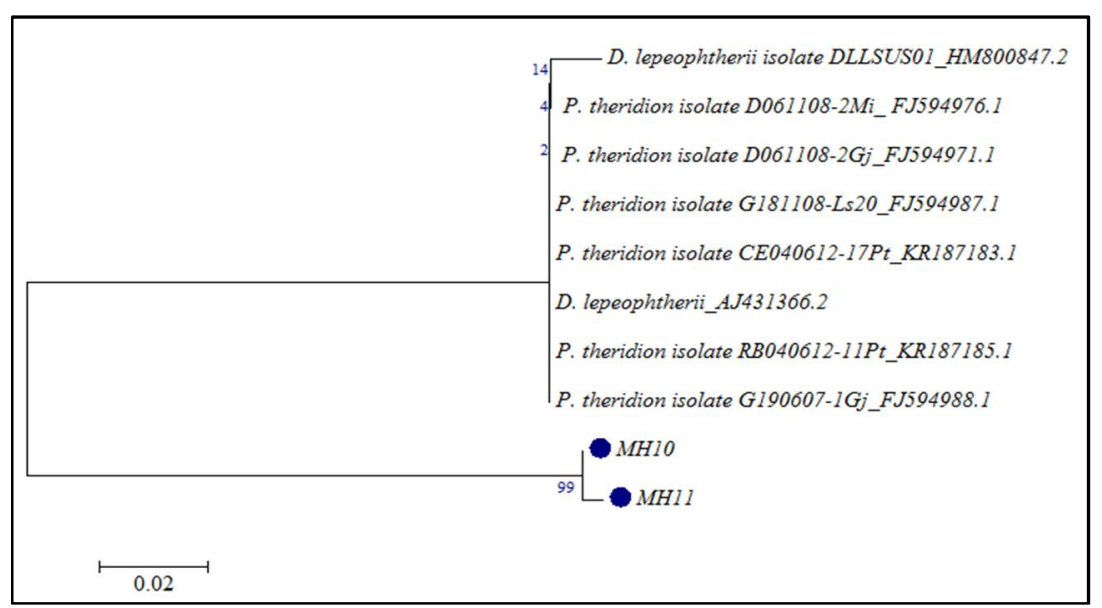

Fig. 6. Molecular phylogenetic analysis by maximum likelihood method. The Neighbor-Joining phylogenetic tree based on partial SSU rRNA gene sequences. Blue circle indicates position of the studied strains.

Identification of the enterocytozoon hepatopenaei by EHP-510 primer: The same samples were used for the detection of the EHP that were used for SSU rRNA primer. The results were negative for EHP-infected $P$. monodon. The absence of microsporidian parasite Enterocytozoon hepatopenaei (EHP) in shrimp collected from farms is not unquestionable and demands further research on this aspect. Though, EHP does not cause mortality but heavily limits growth and the occurrence of this parasite was reported in black tiger shrimp P. monodon in Thailand (Tourtip et al. 2009), in pond-reared L. vannamei in Vietnam and P. stylirostris in Brunei (Tang et al. 2015). The disease outbreak because of microsporidian parasite E. hepatopenaei spread to India additionally, and its occurrence was accounted in farm-raised L. vannamei (Rajendran et al. 2016).

The present investigation confirms the presence of microsporidian parasites in the Penaeus monodon and helps to report the prevalence of the microsporidian parasite in shrimp farms by microscopic observation and molecular identification. This study also 
indicates a risk of a future outbreak of microsporidiosis and other diseases through microsporidian parasites.

Further research on the presence of microsporidian parasite Enterocytozoon hepatopenaei (EHP) in shrimp is a time demanding issue because their absence is not unquestionable. The possibility of the presence of Paranucleospora theridion may provide an opportunity to study the epidemiology of this parasite like- distribution of disease, profile of the ability of a pathogen to establish an infection, potential role of other shellfish as the source of disease. To unravel the role of this parasite in the production loss of farmed shrimp; study on horizontal and vertical transmission of the parasite, physiological dysfunction due to hepatopancreatic pathology, and the limit of parasitic load required for shrimp mortality are additionally required.

\section{Acknowledgements}

Authors would like to thank INVENT Technologies Ltd. for their generous support during molecular work. They would also like to thank the authority of Centre for Advanced Research in Science, University of Dhaka for providing the facilities to carry out the work on SEM. The study was funded by special allocation research grants by Ministry of Science and Technology of the Govt. of the People's Republic of Bangladesh.

\section{References}

Bell, T.A. and D.V. Lightner. 1988. A handbook of normal penaeid shrimp histology. World Aquaculture Society, Baton Rouge, LA. USA.

Chayaburakul, K., G. Nash, P. Pratanpipat, S. Sriurairatana and B. Withyachumnarnkul. 2004. Multiple pathogens found in growth-retarded black tiger shrimp Penaeus monodon cultivated in Thailand. Dis. Aquat. Organ. 60: 89-96.

Flegel, T.W., Sitdhi-Boonyaratpalin, D.F. Flegan, M. Guerin, Siriporn and Sriurairatana. 1992. High mortality of black tiger prawns from cotton shrimp disease in Thailand. In: Diseases in Asian Aquaculture. (Eds.M. Shariff, R.P. Subasinghe and J.R. Arthur). Fish Health Section Publications, Asian Fisheries Society Publications, Makiti City, Philippines, pp. 181-197.

Hadziavdic, K., K. Lekang, A. Lanzen, I. Jonassen, E.M. Thompson and C. Troedsson. 2014. Characterization of the 18S rRNA gene for designing universal eukaryote specific primers. PloS One. 9: e87624.

Kruijssen, I. Froukje, H. Kelling, K. MeeChee, Jespersen and S. Ponte. 2012. Value chains of selected aquatic products from four Asian countries. A review of literature and secondary data. Deliverable report 5.1 of the Sustaining Ethical Aquaculture Trade (SEAT) project. 89 pp. 
Kumar, S., G. Stecher and K. Tamura. 2016. MEGA7: Molecular Evolutionary Genetics Analysis version 7.0 for bigger datasets. Mol. Biol. Evol. 33:1870-1874.

Newman, S.G., 2015. Microsporidian impacts shrimp production-industry efforts address control, not eradication. Glob. Aquac. Advocate 33-35 (March/April 2015).

Nylund, S., A. Nylund, K. Watanabe, C.E. Arnesen and E. Karlsbakk. 2010. Paranucleospora theridion n. gen., n. sp. (Microsporidia, Enterocytozoonidae) with a life cycle in the salmon louse (Lepeophtheirus salmonis, Copepoda) and Atlantic salmon (Salmo salar). J. Eukaryot. Microbiol. 57: 95-114.

Nylund, S., L. Andersen, I. Sevareid, H. Plarre, K. Watanabe, C.E. Arnesen, E. Karlsbakk and A. Nylund. 2011. Diseases of farmed Atlantic salmon Salmo salar associated with infections by the microsporidian Paranucleospora theridion. Dis. Aquat. Organ. 94: 41-57.

Olson, R.E. and C.N. Lannan. 1984. Prevalence of microsporidian infection in commercially caught pink shrimp, Pandalusjordani. J. Invertebr. Pathol. 43: 407-413.

Owens, L. and S. Hall-Mendelin. 1990. Diseases relevant to penaeid mariculture in tropical Australia. In: Pathology in marine science. (Eds. F.O. Perkins and T.C. Cheng), USA Academic Press, San Diego, 421-432 pp.

Rajendran, K.V., S. Shivam, P.E. Praveena, J.J.S. Rajan, T.S. Kumar, S. Avunje, V. Jagadeesan, S.V. Prasad, A. Pande, A.N. Krishnan, S.V. Alavandi and K.K. Vijayan. 2016. Emergence of Enterocytozoon hepatopenaei (EHP) in farmed Penaeus (Litopenaeus) vannamei in India. Aquaculture. 454: 272-280.

Tang, K.F.J., C.R. Pantoja, R.M. Redman, J.E. Han, L.H. Tran and D.V. Lightner. 2015. Development of in situ hybridization and PCR assays for the detection of Enterocytozoon hepatopenaei (EHP), a microsporidian parasite infecting penaeid shrimp. J. Invertebr. Pathol.130: 37-41.

Toubiana, M., O. Guelorget, J.L. Bouchereau, H.L. Brun and A. Marques. 2004. Microsporidians in penaeid shrimp along the west coast of Madagascar. Dis. Aquat. Organ. 58: 79-82.

Tourtip, S., S. Wongtripop, G.D. Stentiford, K.S. Bateman, S. Sriurairatana, J. Chavadej, K. Sritunyalucksana, and B. Withyachumnarnkul. 2009. Enterocytozoon hepatopenaei sp. nov. (Microsporida: Enterocytozoonidae), a parasite of the black tiger shrimp Penaeus monodon (Decapoda: Penaeidae): Fine Structure and phylogenetic relationships. J. Invertebr. Pathol. 102: 21-29. 